\title{
DISEMINASI TEKNOLOGI PEMBUATAN PAKAN TERNAK BERBASIS KULIT BUAH KAKAO FERMENTASI UNTUK MENDUKUNG USAHA PENGGEMUKAN SAPI BALI YANG RAMAH LINGKUNGAN
}

\author{
Bulkaini $^{1 *}$, M. Ashari ${ }^{2}$, Mastur ${ }^{3}$, Ni Wayan Siti ${ }^{4}$ \\ ${ }^{1,2,3}$ Fakultas Peternakan, Universitas Mataram, Nusa Tenggara Barat, Jalan Majapahit 62, Mataram \\ ${ }^{4}$ Fakultas Peternakan, Universitas Udayana, Bukit Jimbaran, Badung, Bali \\ *Email Korespondensi: b_kaini@yahoo.com
}

\begin{abstract}
ABSTRAK
Kegiatan diseminasi dilakukan di Kelompok peternak sapi Baru Sadar Dusun Cupek, Desa Sigar Penjalain, Kecamatan Tanjung, Lombok Utara NTB, dan Kelompok Remaja Masjid Nurul Yakin. Kegiatan ini bertujuan untuk meningkatkan kesejahteraan anggota kelompok peternak dan kelompok remaja masjid melalui program penggemukan sapi ramah lingkungan. Permasalahan kelompok peternak adalah usaha penggemukan sapi masih bersifat peternakan rakyat (belum berorientasi bisnis), dukungan terhadap penerapan IPTEK rendah, penataan kandang dan lingkungan belum ditangani secara optimal. Sedangkan permasalahan kelompok remaja masjid adalah belum adanya unit usaha yang berorientasi bisnis. Solusi penyelesaian permasalahan adalah melakukan pelatihan manajemen pengelolaan peternakan, pengolahan kotoran ternak sistem biokonversi menjadi biogas, pupuk organik padat, demplot penerapan TTG pembuatan pakan sapi berbasis kulit buah kakao fermentasi, penerapan TTG pupuk organik padat dan biogas, dan menata kandang sapi dengan sistem "Ala Lesehan". Hasil kegiatannya adalah pemanfaatan pakan ternak berbasis kulit buah kakao fermentasi dalam bentuk konsentrat dan wafer yang memberikan pertambahan bobot badan sapi Bali sebesar $0,568 \mathrm{~kg} / \mathrm{ekor} / \mathrm{hari}$. Instalasi biogas dengan kapasitas $4 \mathrm{~m}^{3}$ dapat memproduksi biogas sebesar $1,08 \mathrm{~m}^{3} /$ hari, dan produksi bio-slurry 31,033 liter/hari. Pendapatan kelompok remaja masjid dari penjualan pupuk organik padat sebesar 1.461.600/bulan.
\end{abstract}

Kata kunci : Biokonversi, Biogas, Bioslurry, Fermentasi, Kakao

\begin{abstract}
Dissemination activities were carried out at the New Sadar Cattle Breeders Group, Cupek Hamlet, Sigar Penjalain Village, Tanjung District, North Lombok NTB, and the Nurul Yakin Mosque Youth Group. This activity aims to improve the welfare of members of farmer groups and mosque youth groups through an environmentally friendly cattle fattening program. The problem of the farmer group is that the business of fattening cattle is still in the form of people's farms (not yet businessoriented), support for the application of science and technology is low, the arrangement of stables and the environment has not been handled optimally. Meanwhile, the problem of the mosque youth group is the absence of a business-oriented business unit. The solution to the problem is to carry out training in animal husbandry management, processing livestock manure in the bioconversion system into biogas, solid organic fertilizer, demonstration plots for the application of TTG for making cow feed based on fermented cacao pods, applying TTG solid organic fertilizer and biogas, and arranging cow sheds with the "Ala Lesehan". The result of this activity is the use of fermented cocoa pod husk based animal feed in the form of concentrate and wafers which give Bali cattle body weight gain of $0.568 \mathrm{~kg} / \mathrm{head} /$ day. The biogas plant with a capacity of $4 \mathrm{~m} 3$ can produce biogas of $1.08 \mathrm{~m} 3 /$ day, and bio-slurry production of 31.033 litres/day. The income of the mosque youth group from selling solid organic fertilisers was 1,461,600 / month.
\end{abstract}

Keywords : Bioconversion, Biogas, Bioslurry, Cocoa, Fermentation.

\section{PENDAHULUAN}

Kabupaten Lombok Utara (KLU) dengan luas $809,53 \mathrm{~km}^{2}$ terdiri atas 5 kecamatan yaitu Kecamatan Pemenang, Kecamatan Tanjung, Kecamatan Gangga, Kecamatan 
Kayangan, dan Kecamatan Bayan. Kecamatan terluas adalah Bayan sebasar $329,1 \mathrm{~km}^{2}$ disusul Kecamatan Gangga dengan luas $157,35 \mathrm{~km}^{2}$ sedangkan wilayah terkecil adalah Kecamatan Tanjung dengan luas $81,09 \mathrm{~km}^{2}$. Penduduk KLU pada tahun 2016 mencapai 214.393 jiwa, terdiri dari 106,373 laki-laki dan 108.020 perempuan dengan tingkat kepadatan $3.776 \mathrm{jiwa} / \mathrm{km}^{2}$. Hal ini menunjukkan bahwa penduduk KLU termasuk kategori masih longgar (BPS Kabupaten Lombok Utara, 2019).

KLU khususnya Kecamatan Tanjung merupakan salah satu kecamatan yang terkena musibah Gempa Bumi dengan kekuatan 7,0 SR pada tanggal 5 Agustus 2018 (gempa pertama) yang disusul dengan gempa yang kedua dengan kekuatan 6,2 SR terjadi pada tanggal 9 Agustus 2018, mengakibatkan kerusakan fasilitas umum (gedung perkantoran, rumah sakit, gedung sekolah dan rumah ibadah), rumah penduduk dan fasilitas lainnya hampir 90-95\%. Terkait dengan peristiwa alam ini dan dalam rangka pemulihan perekonomian kelompok tani ternak (KTT) di wilayah Kecamatan Tanjung dipandang perlu dilakukan upaya pengembangan ternak potong melalui usaha penggemukan sapi bali di KTT "Baru Sadar" Dusun Cupek, Desa Sigar Penjalin, Kecamatan Tanjung dengan alasan karena dari segi geografi Kecamatan Tanjung merupakan wilayah yang masih tersedia lahan pertanian seluas 714 ha, padang rumput 2.365 ha, dan tanah perkebunan seluas 2.919 ha.

Pada tahun 2016 jumlah ternak sapi bali di KLU tercatat sebanyak 84.613 ekor yang tersebar di lima Kecamatan. Kecamatan Tanjung sebagai lokasi Program Pengembangan Desa Mitra (PPDM) memiliki populasi ternak sapi sebanyak 13.656 ekor $(16,14 \%)$ dari jumlah populasi (BPS Kabupaten Lombok Utara, 2019). Pemeliharaan ternak sapi di Kecamatan Tanjung KLU menghadapi beberapa kendala setelah terjadinya gempa bumi antara lain adalah kandang dan semua fasilitasnya rusak $85 \%$. Permasalahan ini dipertajam lagi dengan permasalahan sebelum terjadi gempa bumi yaitu usaha peternakan masih bersifat peternakan rakyat yaitu belum berorientasi bisnis, dukungan terhadap penerapan iptek masih rendah, dan terbatasnya permodalan. Kendala-kendala ini sangat mempengaruhi kelemahan pada aspek-aspek lainnya seperti skala usaha yang relatif kecil, rendahnya input teknologi, rendahnya tingkat pertambahan bobot badan harian $(\mathrm{PBBH})$ yang pada gilirannya berdampak terhadap rendahnya produktivitas, kemampuan penyediaan pakan ternak dan rendahnya pendapatan usaha di bidang peternakan. Berbagai kendala biologis dan teknis tersebut diperbesar pula dengan kendala dari sisi peternak sapi itu sendiri yaitu masih rendahnya tingkat pengetahuan mereka dalam mengadopsi dan menerapkan teknologi dan manajemen pemeliharan ternak sapi, khususnya sapi potong untuk tujuan penggemukan.

Target mitra PPDM adalah 2 kelompok produktif yaitu kelompok Tani Ternak (KTT) "Baru Sadar" dan kelompok Remaja Masjid "Nurul Yakin" yang ada Dusun Cupek Desa Sigar Penjalin Kecamatan Tanjung Kabupaten Lombok Utara (lokasi gempa bumi). Kelompok Tani Ternak tersebut bergerak dibidang ekonomi produktif yaitu usaha penggemukan sapi yang dibentuk sejak tahun 2009, diresmikan oleh Kepala Dinas Ketahanan Pangan dan Pertanian KLU tahun 2011 dengan susunan pengurus yaitu Ketua: Zohri, Sekretaris: M.Hafiz dan Bendahara: Suhardi. Kelompok peternak ini memiliki area seluas 9 Are. Pada Awal pembentukan kelompok peternak ini memilki 15 ekor sapi dengan status pemilikan ternak yaitu milik pribadi masing-masing anggota peternak sapi. Kondisi kandang Kelompok Tani Ternak yang ada dusun Cupek, Desa Sigar Penjalin baik sebelum dan setelah gempa bumi sangat perlu direnovasi sehingga pertumbuhan ternak sapi yang ada di kandang tersebut bisa mencapai pertambahan bobot badan harian (PBBH) berkisar 0,4$0,5 \mathrm{~kg} / \mathrm{ekor} / \mathrm{hari}$.

Kelompok Remaja Masjid "Nurul Yakin" dibentuk hampir bersamaan waktunya dengan terbentuknya kelompok Tani Ternak Sapi, yaitu sekitar tahun 1999 yang pada awal terbentuknya bergerak dibidang keagamaan yaitu mengkoordinir kegiatan pengajian. Tiga tahun kemudian (tahun 2002) kelompok remaja masjid ini bergabung dengan kelompok peternak Ayam Arab yang ada di lingkungan Sigar Penjalin dibawah binaan Pusat Penelitian Agribisnis (P2A) Universitas Mataram. Dalam kegiatan Program Pengembangan Desa Mandiri (PPDM) anggota kelompok remaja masjid akan dilatih bersama-sama anggota 
kelompok Tani Ternak dalam hal pembuatan pakan ternak sapi yang berbasis bahan lokal berupa kulit buah kakao (KBK) dan limbah pertanian lainnya (jerami padi, jerami kacangkacangan) serta pelatihan pembuatan pupuk organik padat dan pupuk organik cair yang berbasis limbah biogas yang disebut Bioslurry. Kelompok Remaja Masjid "Nurul Yakin" diharapkan untuk bersinergi dengan kelompok tani ternak terutama dalam hal pemanfaatan pupuk organik padat dan cair yang dihasilkan dari limbah kandang untuk menjadi pupuk tanaman makanan ternak, tanaman sayur-sayuran dan tanaman Apotek Hidup.

Pemeliharaan ternak sapi di kandang kelompok tani ternak, khususnya di Dusun Cupek Desa Sigarpenjalin Kecamatan Tanjung menghadapi beberapa permasalahan prioritas yang menjadi kesepakatan bersama untuk ditangani melalui kegiatan diseminasi teknologi, antara lain: 1) Usaha penggemukan sapi yang masih bersifat peternakan rakyat dan belum berorientasi bisnis, 2) Masih rendahnya tingkat pengetahuan peternak sapi dalam mengadopsi dan menerapkan teknologi penggemukan sapi, seperti teknologi pengolahan pakan berbasis kulit buah kakao fermentasi dan pengolahan kotoran ternak dengan biokonversi menjadi biogas dan pupuk organik/kompos dan 3) Penataan kandang dan lingkungan sekitar kandang kelompok yang selama ini belum ditangani secara optimal.

Permasalahan-permasalahan tersebut di atas sangat mempengaruhi kelemahan pada aspek lainnya seperti: skala usaha yang relatif kecil, rendahnya input teknologi, rendahnya tingkat reproduksi yang pada gilirannya berdampak terhadap rendahnya produktivitas, kemampuan penyediaan pakan ternak dan rendahnya pendapatan usaha di bidang peternakan. Dalam rangka membantu memecahkan berbagai masalah dan kendala tersebut di atas serta upaya pemberdayaan ekonomi masyarakat khususnya peternak maka perlu dilakukan kegiatan diseminasi teknologi pembuatan pakan berbasis kulit buah kakao fermentasi untuk mendukung usaha penggemukan sapi bali yang ramah lingkungan.

Solusi yang ditawarkan dalam upaya mengatasi permasalahan antara lain: 1) Memberikan pelatihan kepada anggota kelompok peternak tentang bagaimana memilih bakalan yang baik, cara pendugaan umur sapi, manajemen pakan, perkandangan, pemeliharaan kesehatan, lama peng-gemukan yang ideal, pengolahan kulit buah kakao menjadi pakan sapi, pengolahan kotoran ternak dengan biokonversi menjadi biogas dan pupuk organik/kompos dan analisis usaha penggemukan sapi, 2) Pembuatan demplot: penerapan teknologi tepat guna (TTG) pembuatan pakan sapi bali yang berbasis kulit buah kakao fermentasi, penerapan teknologi tepat guna (TTG) pembuatan kompos, dan TTG pembuatan biogas dan 3) Menata kandang sapi dengan sistem "Ala Lesehan" yaitu satu unit instalasi biogas dilengkapi dengan brugak (bahasa sasak). Brugak adalah : tempat diskusi atau duduk santai dengan kapasitas 4-6 orang, tergantung ukurannya.

Target luaran program antara lain 1). Dihasilkan 3 jenis TTG yaitu: TTG manajemen pemeliharan sapi bali (cara memilih bakalan yang baik dan pendugaan umur sapi bali, manajemen pakan, sistem perkandangan, penanganan kesehatan ternak dan lama penggemukan yang ideal), TTG pengolahan kulit buah kakao menjadi pakan sapi bali yang berkualitas dan TTG. Pengolahan kotoran ternak dengan biokonversi menjadi biogas dan pupuk organik atau kompos; 2) Produk pakan sapi bali berbasis kulit buah kakao fermentasi, 3) Pertambahan bobot badan harian (PBBH) sapi bali mencapai $>0,5 \mathrm{~kg} / \mathrm{ekor} / \mathrm{hari}, 4)$ Dihasilkannya kompos/pupuk organik yang berkualitas dan terbangunnya instalasi biogas yang dilengkapi dengan brugak. Luaran ilmiah yang dihasilkan adalah artikel ilmiah dalam jurnal nasional ber ISSN, artikel populer yang dimuat dalam media lokal (Lombok Post) dan paten sederhana.

Artikel ini memuat tentang: (1) Latar belakang atau landasan ilmiah terkait pelaksanaan kegiatan. (2) Kondisi eksisting kelompok usaha kecil/menengah, kelompok masyarakat atau desa; (3) Permasalahan yang muncul dan menjadi fokus pelaksanaan kegiatan, dapat berupa tantangan PT, persoalan atau kebutuhan usaha kecil/menengah, kelompok masyarakat atau desa; (4) Kebaruan ipteks yang akan diaplikasikan sebagai solusi untuk mencapai tujuan utama kegiatan, (5) Metode penelitian, (6) Hasil dan Pembahasan serta (7) Dampak dan manfaat yang dapat dirasakan oleh mitra. 


\section{METODE}

\section{Metode Diseminasi}

Paket teknologi yang akan di diseminasikan dilakukan dengan metode pendekatan PRA (Participatory Research Appraisal) yaitu dirancang secara bersama-sama antara pihak tim pelaksana dengan anggota mitra/masyarakat. Paket teknologi yang dirancang secara bersama-sama adalah paket teknologi pembuatan pakan Sapi Bali yang berbasis kulit buah kakao fermentasi. Metode yang diterapkan dalam kegiatan fermentasi adalah metode biokonversi dengan menggunakan inokulum non komersial (air kelapa) (Gufran, 1995). Diagram alir pembuatan pakan sapi Bali berbasis KBK fermentasi terlihat pada Gambar 1.

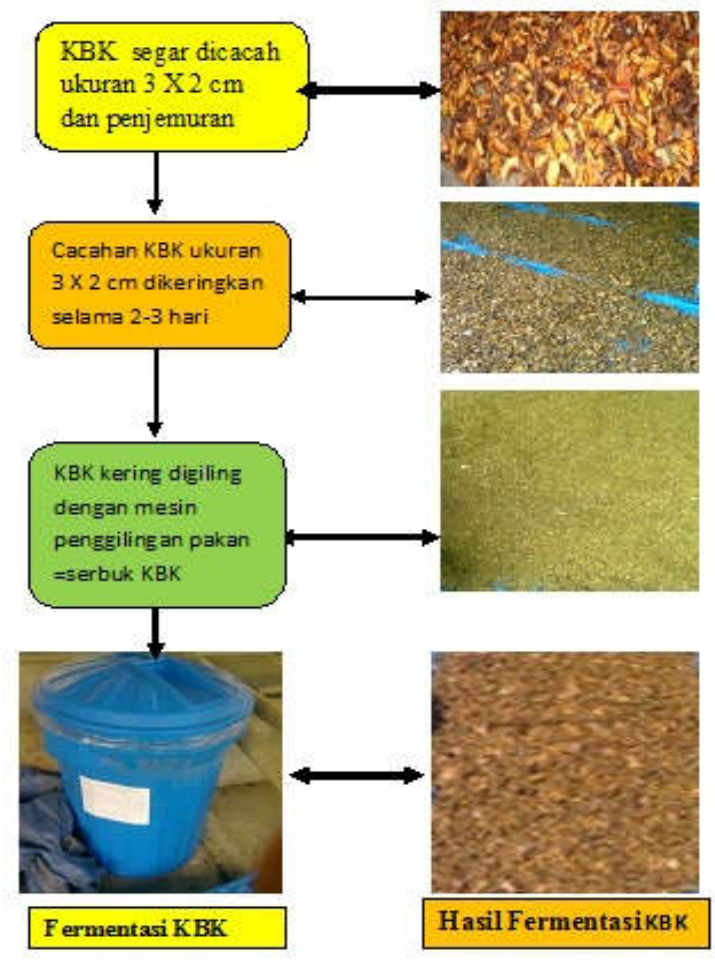

Gambar 1. Diagram alir pembuatan KBK fermentasi

\section{Pembuatan Konsentrat KBK Fermentasi}

Pembuatan pakan konsentrat KBK fermentasi disusun dengan formula: 30\% KBK fermentasi +10 dedak $+60 \%$ rumput lapangan/jerami jagung. Hasil campuran dari ketiga bahan pakan tersebut dilakukan pengeringan dengan cara diangin-anginkan.

\section{Pembuatan wafer kulit kakao}

KBK yang sudah difermentasi dilakukan proses pencetakan dengan menggunakan alat pencetak secara manual, Pada saat pencetakan, alat pencetak dipanaskan secara perlahan-lahan dengan kompos gas elpiji. Adapun bentuk alat pencetak pakan terlihat pada Gambar 2. Pakan dalam bentuk wafer kulit kakao terlihat pada Gambar 3.

\section{Pembuatan Instalasi Biogas}

Instalasi biogas yang dibangun adalah instalasi biogas yang dilengkapi dengan Brugak sebagai tempat istirahat atau sebagai rumah jaga para anggota kelompok ternak. Adapun rancang bangun instalasi biogas yang ditawarkan terlihat pada Gambar 4.

Memuat cara dan tahapan dalam menyelesaikan masalah yang menjadi target kegiatan. Metode aplikasi Ipteksnya bisa berupa (1) Substitusi Ipteks. Untuk kegiatan yang menawarkan ipteks baru, lebih modern dan efisien kepada usaha kecil/menengah, kelompok 
masyarakat atau desa dengan menggantikan penguasaan ipteks lama. (2) Difusi Ipteks. Untuk kegiatan dari gabungan beberapa ipteks dan menghasilkan produk. (3) Pelatihan Untuk kegiatan penyuluhan, demonstrasi dan melatih mengoperasikan sistem atau peralatan yang dihibahkan. (4) Pendampingan. Untuk kegiatan usaha kecil/menengah atau masyarakat yang diselesaikan melalui jasa konsultasi. (5) Pendidikan Masyarakat. Untuk kegiatan penyuluhan yang bertujuan meningkatkan kesadaran masyarakat (bidang hukum, agama, peraturan, dll). Jika ada proses analisis dan pengolahan data perlu dijelaskan dalam metode ini. Perlu dijelaskan tahapan proses monitoring dan evaluasi terhadap pelaksanaan program beserta metodenya.

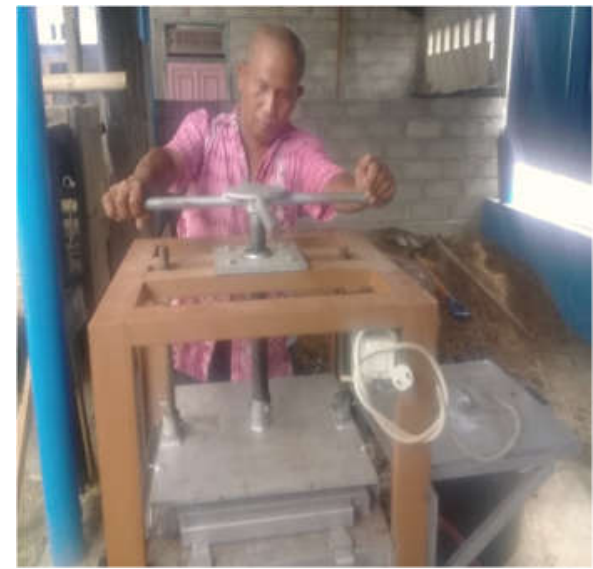

Gambar 2. Alat pencetak wafer kulit kakao

Gambar 4. Instalasi biogas dengan kapasitas $4 \mathrm{~m}^{3}$.

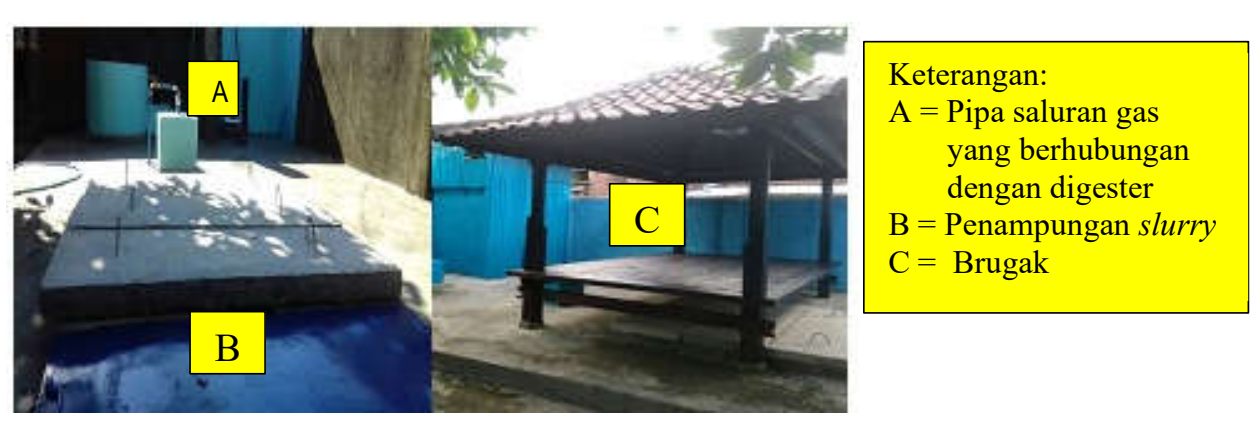

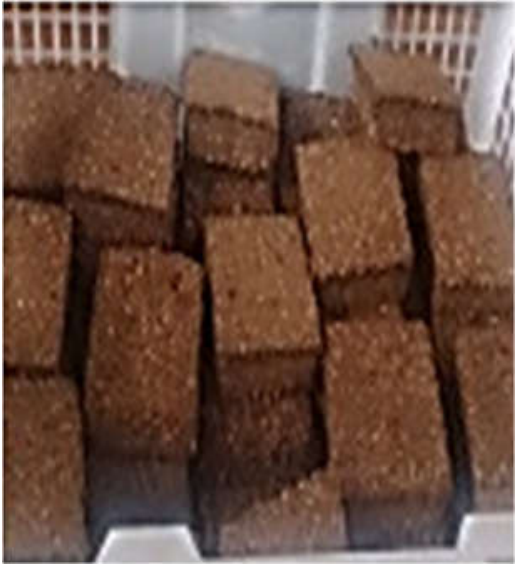

Gambar 3. Pakan berbentuk wafer kulit kakao

Keterangan yang berhubungan dengan digeste $\mathrm{B}=$ Penampungan slurry $\mathrm{C}=$ Brugak

\section{HASIL DAN PEMBAHASAN}

Dalam upaya untuk meningkatkan palatabilitas pakan sapi bali dalam bentuk konsentrat berbasis KBK fermentasi dilakukan pemberian pakan secara bertahap yaitu sapi dibiarkan dalam kondisi yang lapar dulu baru diberikan pakan konsentrat berbasis KBK fermentasi (KBKF): Metode pemberiannya adalah menerapkan metode berjejang yang disebut Tiered Method yaitu metode uji coba pakan secara berjenjang. Tahap pertama menggunakan Rasio KBKF: rumput alami $20 \%: 80 \%$, tahap kedua $30 \%: 70 \%$, sedangkan tahap ketiga 40\%:60\%. Durasi waktu pemberian perjenjang selama 1 minggu. Metode pemberian pakan dimaksud terlihat pada Gambar 5.

Hasil pengamatan menunjukkan bahwa rasio pakan KBKF dengan pakan alami (20\% : 80\%) dalam jangka 2-3 hari pakan tersebut disukai oleh ternak sapi, sehingga pada hari 4-7 dikasi pakan dengan rasio 30\%: 70\%. Selanjutnya pada hari 8 sampai seterusnya diberi pakan dengan rasio 40\%:60\%. Dalam penggunaan pakan KBKF menggunakan 6 ekor sapi yang dibagi menjadi 2 kelompok yaitu 3 ekor diberi pakan secara konvensional dan 3 
ekor diberi pakan KBKF + jerami jagung. Variabel yang diukur yaitu pertambahan bobot badan harian (PBBH) sapi bali, konsumsi pakan dan efisiensi Penggunaan Ransum.

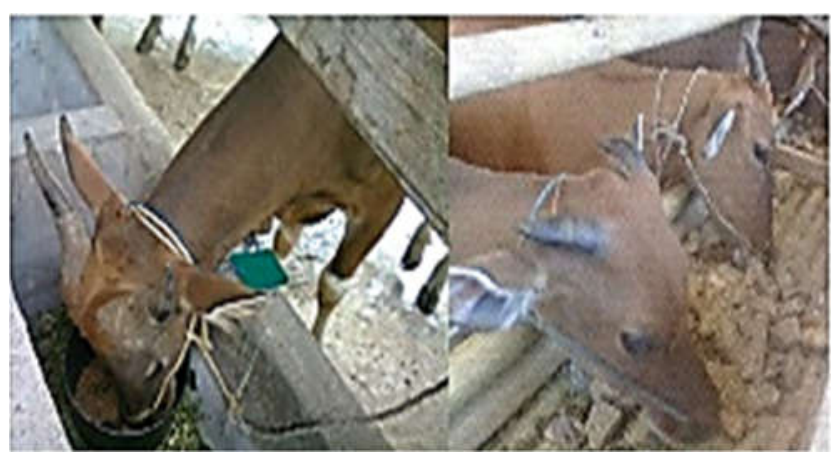

Gambar 5. Pemberian pakan berbentuk wafer kulit kakao

\section{Pertambahan Bobot Badan Harian (PBBH)}

Pertambahan bobot badan merupakan salah satu parameter yang dapat digunakan sebagai tolak ukur produktivitas ternak khususnya ternak potong. Hasil percobaan menunjukkan bahwa kelompok sapi yang diberi pakan konvensional pertambahan bobot badan harian $(\mathrm{PBBH})$ lebih rendah dibandingkan dengan kelompok sapi yang diberi pakan $50 \%$ KBK fermentasi $+50 \%$ jerami jagung. Rata-rata pertambahan bobot badan harian, konsumsi pakan dan efiensi penggunan pakan selama uji coba disajikan pada Tabel 1.

Tabel 1. Rata-rata pertambahan bobot badan, konsumsi BK dan efisiensi penggunan ransum.

\begin{tabular}{|l|c|c|}
\hline \multirow{2}{*}{\multicolumn{1}{|c|}{ Peubah }} & \multicolumn{2}{c|}{ Kelompok Sapi } \\
\cline { 2 - 3 } & $\begin{array}{c}\text { Pakan } \\
\text { Konvensional }\end{array}$ & $\begin{array}{c}\text { KBK Fermentasi }+ \\
\text { jerami jagung (KBKFJ) }\end{array}$ \\
\hline Bobot Akhir (kg) & 201,250 & 207,250 \\
PBBH (kg/hari) & 0,376 & 0,568 \\
Konsumsi BK (kg/ekor/hari) & 5,188 & 5,498 \\
Konsumsi BK (\% BB) & 2,893 & 2,678 \\
Efisiensi penggunaan ransum & 0,255 & 0,304 \\
\hline
\end{tabular}

Keterangan: $\mathrm{PBBH}=$ Pertambahan Bobot Badan Harian; BK $=$ Bahan Kering.

Pada Tabel 1 terlihat bahwa PBBH yang tinggi sejalan dengan terjadinya peningkatan konsumsi pakan. Konsumsi pakan yang tinggi akan diikuti dengan pertambahan bobot badan harian yang tinggi. Rasio antara konsumsi pakan dengan PBBH sapi bali jantan yang diberi pakan konversional yaitu 1:0,07, ini berati bahwa setiap pemberian $1 \mathrm{~kg}$ pakan berdasarkan bahan kering memberikan penambahan bobot badan harian sebesar $0,07 \mathrm{~kg} / \mathrm{hari}$. Selanjutnya rasio antara konsumsi pakan dengan PBBH sapi bali jantan yang diberi pakan KBKFJ yaitu 1:0,103, ini berati bahwa setiap pemberian $1 \mathrm{~kg}$ pakan berdasarkan bahan kering memberikan pertambahan bobot badan harian sebesar $0,103 \mathrm{~kg} / \mathrm{ekor} / \mathrm{hari}$. Hasil percobaan ini membuktikan bahwa keseimbangan gizi dalam ransum memberikan andil yang cukup signifikan terhadap penampilan produksi ternak sapi bali. Sapi Bali sangat responsif terhadap usaha-usaha perbaikan pakan (Bandini, 1999). Pertambahan Bobot Badan harian sapi bali tertinggi $(0,568 \mathrm{~kg} / \mathrm{ekor} / \mathrm{hari})$ dicapai dengan pemberian pakan $50 \% \mathrm{KBK}$ fermentasi. Hasil penelitian sapi bali yang lain menunjukkan bahwa pertambahan bobot badan harian berkisar antara 0,372 -0,552 kg/ekor/hari (Handoko, 1998).

Sapi bali jantan yang dipelihara dengan sistem kereman pertambahan bobot badannya mencapai 0,34 - 0,49 kg/ekor/hari (Bandini, 1999). Sapi bali dengan dengan ransum rumput gajah $40 \%+$ konsentrat $60 \%(20,7 \% \mathrm{PK}, 77 \% \mathrm{TDN})$ mempunyai 
pertambahan berat badan sebesar 0,760 kg/ekor/hari (Mastika, 2003). Selanjutnya sapi bali dengan pemberian pakan KBK dalam bentuk fermentasi sebanyak $4 \mathrm{~kg} / \mathrm{ekor} / \mathrm{hari}$ dan dapat menghasilkan pertambahan bobot badan sebesar 1,21 kg/hari (Anas, Zubair and Rohmadi, 2011) dan 0,9 kg/ekor/hari (Saputra, 2012).

Tercapainya PBBH yang lebih tinggi pada kelompok ternak yang mendapat ransum yang mengandung 50\% KBK fermentasi disebabkan oleh tercapainya keseimbangan ekosistem di dalam rumen yang disebabkan oleh keserasian nutrien penyusun ransum yang menunjang terjadinya hubungan yang sinergis antara mikroba di dalam rumen. Hal ini mempunyai implikasi terhadap kecernaan pakan yang lebih tinggi sehingga ternak mendapat pasokan nutrien lebih tinggi dan pada akhirnya pertumbuhan ternak menjadi lebih tinggi.

\section{Konsumsi Pakan}

Perlakuan pakan tidak memberikan adanya perbedaan yang berarti terhadap konsumsi bahan kering pakan. Hal tersebut mencerminkan bahwa pemberian KBK fermentasi $50 \%$ maupun dengan $25 \%$ dalam ransum tidak sampai pada taraf yang mengganggu selera makan ternak percobaan, sehingga konsumsi tidak terganggu. Konsumsi ransum pada dasarnya ditujukan untuk memenuhi kebutuhan energi ternak, sehingga ternak akan berhenti makan apabila ternak merasa tercukupi kebutuhan energinya. Namun, apabila ransum tidak padat energi (tinggi serat) maka daya tampung alat pencernaan, terutama organ pencernaan fermentatif akan menjadi faktor pembatas utama konsumsi ransum, meskipun sesungguhnya masih memerlukan tambahan energi. Pada Tabel 1, nilai konsumsi bahan kering berkisar 5,188-5,498 kg/ekor/hari atau rata-rata 5,343 kg/ekor/hari. Angka ini relatif sama dengan hasil penelitian sebelumnya yang menunjukkan bahwa konsumsi bahan kering harian sapi bali yang diberi ransum jerami padi amonisi + minyak jagung + Analog Hidroksi Metionin sebesar 5,358 kg/ekor/hari (Handoko, 1998). Bila konsumsi bahan kering ransum dinyatakan dalam persen bobot badan, maka rataan konsumsinya adalah $2.77 \pm 0.11 \%$ dari bobot badan. Konsumsi bahan kering ransum penelitian yang lain menunjukkan angka sebesar1,4 - 3 persen dari bobot badan (Anas, Zubair and Rohmadi, 2011).

\section{Efisiensi Penggunaan Ransum}

Nilai efisiensi penggunaan ransum memiliki arti penting dalam proses produksi ternak, dan sering dijadikan sebagai dasar untuk mengambil keputusan. Hasil percobaan menunujukkan bahwa kelompok sapi yang diberi pakan konvensional dengan kelompok sapi yang diberi pakan KBK Fermentasi+jerami jagung terdapat perbedaan dalam hal efisiensi penggunaan ransum sapi bali jantan yang digemukkan secara feedloting. Hasil uji coba memperlihatkan bahwa sapi bali jantan yang diberi pakan KBK fermentasi air kelapa mempunyai nilai efisiensi penggunaan ransum lebih tinggi $(0,304)$ dibandingkan nilai efisiensi ransum sapi yang diberikan pakan secara konvensional $(0,255)$.

Hasil percobaan memperlihatkan bahwa peningkatan pertambahan bobot badan sapi Bali yang lebih tinggi terjadi pada kelompok sapi yang mendapat perlakuan pakan KBK fermentasi + jerami jagung yang diikuti oleh peningkatan konsumsi bahan kering ransum. Rataan pertambahan bobot badan harian (PBBH) sapi Bali pada kelompok II relatif lebih tinggi dibandingkan dengan sapi Bali kelompok I. Hal ini membuktikan bahwa tingkat keserasian gizi ransum akan menentukan nilai guna (utility) ransum. Hasil penelitian ini mengindikasikan bahwa sapi Bali dengan pemberian pakan KBK fermentasi air kelapa dalam bentuk serbuk bisa mengganti konsentrat komersial sebagai pakan dengan tingkat $\mathrm{PBBH}$ yang relatif sama dengan $\mathrm{PBBH}$ sapi Bali yang diberi pakan konsentrat komersial. Hal ini mungkin disebabkan karena KBK fermentasi air kelapa dalam bentuk serbuk mampu memberikan keseimbangan produk metabolisme dalam alat pencernaan sehingga mengakibatkan nilai guna pakan menjadi meningkat.

\section{Produksi Gas dan Bio-slurry per hari.}

Pengukuran produksi biogas dilakukan dengan cara mengukur debit biogas yang keluar dari digester. Pengukuran produksi biogas dilakukan selang 12 jam setiap hari yaitu pada puku 08.00 dimasukkan kotoran sapi dicampur dengan air dengan rasio 1:1 sampai 
campuran homogen. Setelah 12 jam, baru dilakukan pengukuran produksi biogas. Pengukuran dengan menggunakan alat ukur gasbio (flow-meter), selain itu dilakukan pula pengukuran produksi slurry dengan mengukur volume yang dihasilkan selama 24 jam di Kandang Kelompok peternak sapi Bahtera Damai Desa Sembalun Kecamatan Sekarbela Kota Mataram. Data produksi biogas digunakan sebagai indikator keberhasilan penerapan instalasi biogas.

Berdasarkan pengamatan yang diakukan oleh tim pengabdian ditemukan bahwa produksi gas dan slury selama 30 hari pengamatan diperoleh rata-rata $11,08 \mathrm{~m}^{3} /$ hari, dengan volume slury perhari 31,033 liter/hari. Untuk menghasilkan $1,08 \mathrm{~cm}^{3}$ gas diperlukan $\pm 30 \mathrm{~kg}$ feces sapi dan 30 liter air (1:1). Jumlah feces sapi yang diperlukan untuk menghasilkan gas sebanyak $1 \mathrm{~m}^{3}$ sebanyak 40-45 $\mathrm{kg}$ (Samiadi and Bulkaini, 2015). $1 \mathrm{~m}^{3}$ biogas jika dikonverikan dengan arus listrik setara dengan $6 \mathrm{kwh}$, konversi dengan Elpiji setara 0,48 kg, konversi dengan minyak tanah setara 0,62 liter, konversi dengan minyak solar setara 0,52 liter, dan konversi dengan kayu bakar setara 3,5 kg (Syamsiah, 2011). Mengacu standar tersebut maka produksi gas $1,08 \mathrm{~m}^{3} /$ hari setara dengan:
a. $\quad$ Elpiji $=1,08 \times 0,48 \mathrm{~kg}=0,518 \mathrm{~kg}$
b. Minyak tanah $=1,08 \times 0,62=0,670$ liter
c. Minyak solar $=1,08 \times 0,52=0,572$ liter
d. Kayu bakar $=1,08 \times 3,5 \mathrm{~kg}=3,78 \mathrm{~kg}$
e. Listrik $=1,08 \times 6 \mathrm{kwh}=6,48 \mathrm{kwh}=6.480$ watt.

\section{DAMPAK DAN MANFAAT}

Kulit buah kakao yang selama ini tidak terpakai dapat dimanfaatan sebagai campuran pakan ternak dalam bentuk wafer kulit kakao. Pakan ternak ini dapat memberikan Pertambahan Bobot Badan Harian (PBBH) sapi Bali. Instalasi biogas yang dibangun di kandang Kelompok Tani dapat memproduksi biogas dengan produksi bio-slurry. Bio-slurry sebagai limbah biogas dapat digunakan sebagai pupuk organik cair oleh para petani. Sehingga kehidupan para petani dapat lebih baik, karena pendapatan dari hasil penjualan pupuk organik padat, bobot sapi yang dipelihara dapat meningkat yang menggunakan pakan ternak dari bahan yang selama ini belum termanfaatkan.

\section{KESIMPULAN}

Pemanfaatan pakan berbasis kulit buah kakao fermentasi dalam bentuk wafer kulit kakao dapat memberikan Pertambahan Bobot Badan Harian (PBBH) sapi Bali sebesar 0,568 $\mathrm{kg}$ /ekor/hari. Instalasi biogas dengan kapasitas $4 \mathrm{~m}^{3}$ yang dibangun di kandang Kelompok Tani Ternak Dusun Cupek Desa Sigar Penjalin Kecamatan Tanjung Kabupaten Lombok Utara Nusa Tenggara Barat dapat memproduksi biogas sebesar $1,08 \mathrm{~m}^{3} /$ hari dengan produksi bio-slurry sebesar 31,033 liter/hari. Bio-slurry sebagai limbah biogas dapat dimanfatkan langsung oleh petani sebagai pupuk organic cair. Pendapatan dari hasil penjualan pupuk organik padat sebesar 1.461.600/bulan.

\section{UCAPAN TERIMA KASIH}

Ucapan terima kasih disampaikan kepada Kemenristek/BRIN yang telah memberikan dana untuk pelaksanan pengabdian kepada masyarakat skema Program Pengembangan Desa Mandiri (PPDM). Ucapan yang sama juga disampaikan kepada Rektor Universitas Mataram yang telah memberikan ijin untuk melaksanakan kegiatan pengabdian kepada masyarakat. 


\section{REFERENSI}

Anas, S., Zubair, A. and Rohmadi, D. (2011) 'Kajian pemberian pakan kulit kakao fermentasi terhadap pertumbuhan sapi Bali', Gorontalo: Badan Pengkajian Teknologi Pertanian (BPTP).

Bandini, Y. (1999) 'Sapi Bali cocok untuk ternak potong dan kerja, rajin beranak dan mudah pemeliharaannya', Penebar Swadaya. Jakarta.

BPS Kabupaten Lombok Utara (2019) Kabupaten Lombok Utara Dalam Angka. Statistik Kabupaten Lombok Utara. Available at: https://lombokutarakab.bps.go.id/publication/2019/08/16/ee5d955bf05e4641bb970 b53/kabupaten-lombok-utara-dalam-angka-2019.html (Accessed: 15 September 2020).

Gufran (1995) 'Telaah Ragam dan Produksi, Porsi Pemberian dan Konsumsi, Nilai Nutrien Pakan Sapi Bali Jantan Kereman Kaitannya dengan Pertumbuhan'. Laporan Penelitian Fakultas Peternakan Universitas Mataram, Mataram.

Handoko, E. (1998) 'Pengaruh Amoniasi Jerami Padi, Suplementasi Minyak Jagung, dan Analog Hidroksi Methionin Terhadap Pertumbuhan Sapi Bali'. Fakultas Peternakan Universitas Mataram, Mataram.

Mastika, I. M. (2003) 'Feeding Strategies to Improve the Production Performance and Meat Quality of Bali Cattle (Bos Sondaicus)', Australian Centre for International Agriculture Research. Canberra, 110, pp. 10-13.

Samiadi and Bulkaini (2015) Teknologi Pengolahan Kulit dan Hasil Sisa Ternak. Fakultas Peternakan Universitas Mataram, Mataram.

Saputra, T. H. (2012) 'Potensi Limbah Kulit Kakao untk Pakan Ternak Kecamatan Gedong Tataan', Fakultas Pertanian Jurusan Peternakan. Univresitas Lampung, Lampung.

Syamsiah, S. (2011) Sistem Konversi Energi Biogas Menjadi Tenaga (Listrik). Pelatihan Produksi Biogas dan Pupuk Organik. Fakultas Peternakan Universitas Gadjah Mada, Yoyakarta. 